\title{
PROCUREMENT BEHAVIOR OF THE FRUIT AND VEGETABLE INDUSTRY IN SRI LANKA
}

\author{
M. Esham ${ }^{1}$ and K. Usami ${ }^{2}$
}

\begin{abstract}
The fruit and vegetable industry is considered to have the potential to develop backward linkages towards small farmers and so accelerate crop diversification in the paddy dominated non-plantation agriculture in Sri Lanka. Therefore, it may be instrumental to have some understanding of the type of backward linkages used by the industry to procure raw materials, the associated constraints and the industry's perception of small farmers as suppliers. This study utilized data collected from ten fruit and vegetable processors, seven exporters and one of the largest supermarket chains in Sri Lanka. Spot markets, contract suppliers and contract farmers were the three major procurement channels of the fruit and vegetable industry. The industry considered contract farmers as a reliable source of raw material supply. Moreover, the industry had a positive perception of small farmers' ability to be contract-farming partners to supply industry requirements. However, lack of proper organization models to organize small farmers was seen as a major constraint resulting in high cost of establishing and managing linkages with small farmers.
\end{abstract}

Key Words: Fruit and vegetable industry, procurement, contract farming, industry perception, Sri Lanka

\section{INTRODUCTION}

The fruit and vegetable industry in Sri Lanka has the potential to make a significant contribution towards commercialization of non-plantation agriculture. The fruit and vegetable industry is considered to have the potential to develop backward linkages towards small farmers and so accelerate crop diversification in the paddy dominated non-plantation agriculture sector. Moreover, fruits and vegetables are considered as potential candidates for the diversification and commercialization of peasant farming in Sri Lanka (Dunham, 1995). Therefore, it may be instrumental to have some understanding of the type of backward linkages used by the industry to procure raw materials, the associated constraints and the industry's perception of small farmers as suppliers.
The fruit and vegetable industry in Sri Lanka comprise of processors of fruits and vegetables, exporters of fresh and processed fruits and vegetables and the market intermediaries particularly supermarket chains where a certain amount of value adding activities takes place. The majority of the fresh fruit and vegetable exporters and processors can be classified as small and medium scale industries.

The main objectives of this paper are to examine the fruit and vegetable industry procurement behavior and the industry perception of small farmers as suppliers to the industry. First, a brief overview of the fruit and vegetable industry in Sri Lanka followed by a discussion of the channels used to procure fruits and vegetables are presented. Next, the constraints faced by the industry in procuring fruits and vegetables are discussed. Finally, industry perceptions of small farmers

${ }^{1}$ Senior Lecturer, Department of Agribusiness Management, Faculty of Agricultural Sciences, Sabaragamuwa 36

${ }^{2}$ Professor, Faculty of Agriculture, Yamaguchi University, Japan. 
as suppliers to the industry are presented.

\section{Data}

The data for analysis were collected from ten fruit and vegetable processors, seven exporters and the largest supermarket chain in Sri Lanka. The processors and exporters belong to the Sri Lanka Fruit and Vegetable Producers, Processors, and Exporters Association which is the main organization representing the interest of the fruit and vegetable industry in Sri Lanka. A questionnaire was used to collect data from the fruit and vegetable industry on procurement sources, constraints in procurement, and the perception of small farmers as contract partners to supply to the industry.

\section{Fruit and Vegetable Industry}

In Sri Lanka, about 602,000 metric tons of vegetables and 855,000 metric tons of fruits are produced annually. This comprises of over 40 vegetable and 50 fruit varieties grown in different agro-climatic regions. It is estimated that $30-40$ per cent of all fruits and vegetables goes to waste between harvesting and marketing due to poor post-harvest handling (Kudagamage, 1998) while there are absolute problems like poor production technology, lack of markets and underdevelopment of the processing and export industry.

More than 96 per cent of the entire fruits and vegetables produced in the country are locally consumed as fresh products without any addition of value (Table 1). Less than 4 per cent of total production of fruits and vegetables undergo some sort of added-value in the form of export, processing or marketing to the high value market through supermarkets (Esham et al., 2006). The main vegetables that are exported include green beans, leeks, capsicum, cabbage, carrot, tomato, bell pepper and gherkin, while the fruits include pineapple, passion fruit, banana and mango. Tomato, chili and gherkin are the major vegetables used for processing mainly to produce chutney, pickles, sauce and gherkin in brine and vinegar while pineapple, mango, melon and passion fruit are the major fruits used in the fruit processing industry to produce ready to serve beverages, squash and jam.

Table 01: Fruits and vegetables production and exports in Sri Lanka

\begin{tabular}{ccccc}
\hline Year & \multicolumn{2}{c}{$\begin{array}{c}\text { Production (metric } \\
\text { tons) }\end{array}$} & \multicolumn{2}{c}{ Exports (metric tons) } \\
& Fruit & Vegetable & Fruit & Vegetable \\
\hline 1999 & 828,190 & 657,050 & 7,361 & 6,193 \\
2000 & 832,080 & 628,480 & 5,709 & 10,675 \\
2001 & 842,240 & 601,180 & 7,399 & 9,248 \\
2002 & 850,290 & 597,130 & 5,674 & 10,240 \\
2003 & 854,790 & 601,950 & 7,706 & 9,473 \\
\hline
\end{tabular}

Sources: FAOSTAT (2004) and Central Bank of Sri Lanka (2003). 
In the early 1990s there was a significant growth in the export of vegetables with the growth in the export of gherkin. Gherkin in brine and gherkin in vinegar were the major revenue sources in processed food export sector during this period. Gherkin was cultivated for export by a relatively large number of small farmers on production management contracts. In the mid-1990s a number of agribusiness companies were involved in gherkin cultivation with the participation of about 15,000 small farmers (Dunham, 1995). However, from mid-1990s the industry started to decline due to competition mainly from India. Moreover, lack of proper organization models to sustain long term farmers-agribusiness linkages greatly influenced the decline of this industry.

\section{Characteristics of fruit and vegetable processors and exporters}

The sample used for the study comprised of ten processors, seven exporters and one supermarket chain. The processors and exporters belong to the Sri Lanka Fruit and Vegetable Producers, Processors and Exporters Association which is the main organization representing the interest of the fruit and vegetable industry in Sri Lanka. As shown in the Table 2 the majority of the processors and the majority of the export companies are limited liability companies. The processing companies are large-scale operations compared to the exporters in terms of numbers employed, procurements and investment. The processors employee about 180 employees, majority procure more than
150 MT of raw materials per month and own processing equipment worth about Rs. 54 million. While the exporters have an average of 50 employees. The supermarket chain is a public quoted company with more than 2,500 employees. It is the largest supermarket chain in Sri Lanka with more than 50 supermarket outlets in the country.

\section{Procurement channels of the fruit and vegetable industry}

As illustrated in Figure 01, the major procurement channels used by the processors, exporters and the supermarket chain are; spot markets, contract suppliers and contract farmers. Own farm production was negligible as only one company reported producing vegetables in its own farm. Processors use all three major channels while exporters mainly use spot market and contract suppliers to procure fruits and vegetables. As shown in Table 3 contract farming appears to be an important source of fruits and vegetables supply to the industry except for exporters of fresh fruits and vegetables. Fruits and vegetables are supplied by more than 3,800 contract farmers to the processors and the supermarket chain. The supermarket chain being the largest in Sri Lanka with the recent rapid expansion of outlets in the country is extensively using contract farming to meet its fruit and vegetable requirements. Generally, exporters did not use contract arrangements due to small scale of operation, preferring instead to procure fruits and vegetables from the spot market. 
Table 02: Background of fruit and vegetable processing and exporting companies

\begin{tabular}{lrrrrrrrrrrrr}
\hline \multicolumn{1}{c}{ Age of business (years) } & \multicolumn{1}{c}{ No of employees } & \multicolumn{3}{c}{ Total Procurement } \\
(MT/month) & \multicolumn{3}{c}{ Ownership structure } \\
\hline $\begin{array}{l}\text { Process } \\
\text { ors }\end{array}$ & 45 & $5-10$ & $>10$ & $<50$ & $50-150$ & $>150$ & $<50$ & $50-150$ & $>150$ & Partner & Pvt & Plc \\
$\begin{array}{l}\text { Export } \\
\text { ers }\end{array}$ & 2 & 2 & 3 & 5 & 1 & 1 & 5 & 1 & 1 & 2 & 5 & 0 \\
\hline
\end{tabular}

Source: Field survey (2003).

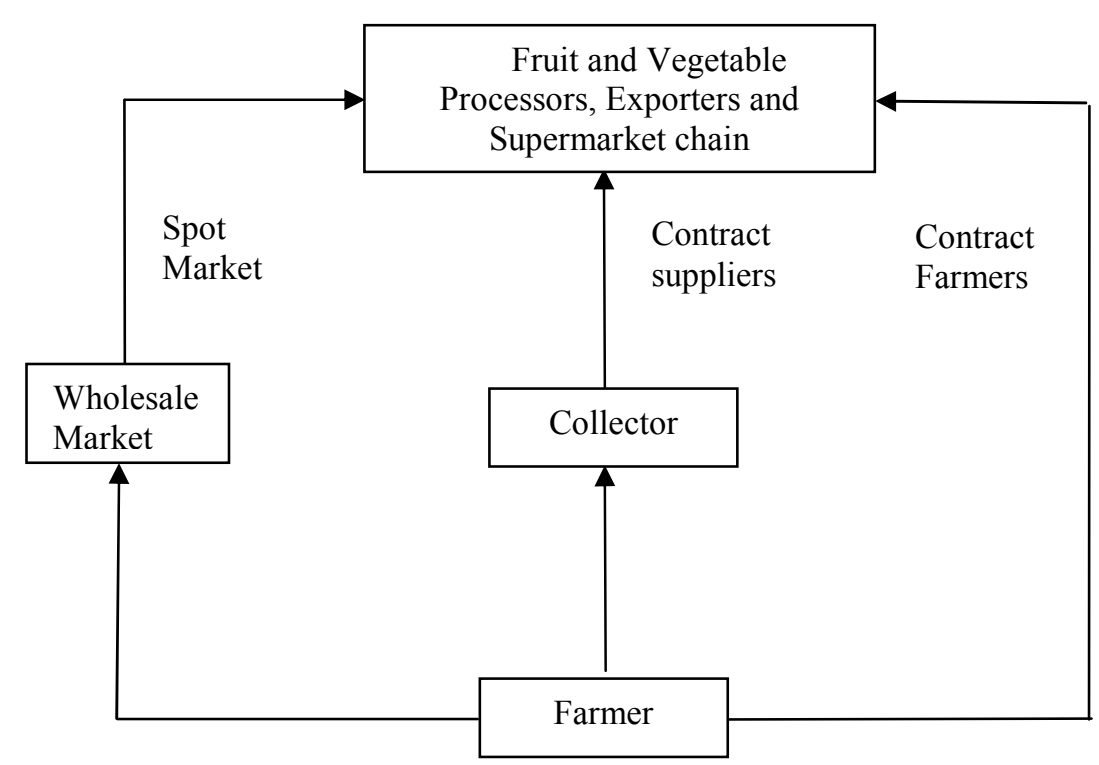

Figure 01: Major procurement channels of the fruit and vegetable industry

Table 03: Procurement by the fruit and vegetable industry

\begin{tabular}{|c|c|c|c|c|c|}
\hline & \multicolumn{3}{|c|}{ Procurement sources in \% } & \multirow{2}{*}{$\begin{array}{l}\text { Volume of } \\
\text { annual } \\
\text { procurements } \\
\text { (MT) }\end{array}$} & \multirow{2}{*}{$\begin{array}{l}\text { No. of } \\
\text { contract } \\
\text { farmers }\end{array}$} \\
\hline & $\begin{array}{l}\text { Spot } \\
\text { market }\end{array}$ & $\begin{array}{l}\text { Contract } \\
\text { suppliers }\end{array}$ & $\begin{array}{l}\text { Contract } \\
\text { farmers }\end{array}$ & & \\
\hline Processor & 18.6 & 36.3 & 45.1 & 10,596 & 3,063 \\
\hline Exporter & 65.0 & 27.6 & 7.0 & 8,676 & 45 \\
\hline $\begin{array}{l}\text { Super market } \\
\text { chain }\end{array}$ & 0 & 25.0 & 75.0 & 7,200 & 750 \\
\hline
\end{tabular}

Source: Field survey (2003).

Note: Data are for ten processors, seven exporters and one supermarket chain. 


\section{Spot markets}

The spot market transaction is a shortterm exchange based on market prices with no prior agreements between the parties. Spot market purchasing is done by either an agent of the company visiting a wholesale market or through independent collectors. Virtually all the companies use the spot market to purchase raw materials. However, small companies and exporters use spot markets to procure more supplies than processors and larger companies. Spot market transactions are also used to obtain raw material supplies when shortfalls from the main procurement source occur. The export companies give preference to the dedicated economic center (a large wholesale market) to procure fruits and vegetables. Many of the smaller export companies are located in close proximity to the dedicated economic center in Colombo.

\section{Contract suppliers}

Contract suppliers have formal agreements with the company to supply raw materials. Moreover, they have long-term relationships with the company. Depending on the requirement of the contract suppliers, they are given cash advances by the company. These contract suppliers' purchase mainly direct from farmers and occasionally from the wholesale market. The majority of contract suppliers have developed long-term relationship with farmers in their geographical areas. Many of these relationships are secured through providing credit, farm inputs like fertilizer and agrochemicals to farmers in return the farmers repay the contract supplier with the produce. Normally contract suppliers deliver raw material to the company premises. As shown in
Table 04, contract suppliers are considered to be more reliable than spot markets. Therefore, to assure an uninterrupted supply of raw materials contract suppliers are preferred over spot markets. Despite the presence of a legal contract, none of the companies stated taking legal action against breach of contract by the contract suppliers.

\section{Contract farmers}

The companies practice all three major types of contract farming such as market specification, resource providing and production management. Market specification contract is a preharvest agreement that binds the company and farmers to a particular set of conditions governing the sale of the harvest. These conditions often specify price, quality and timing of procurement. A resource-providing agreement obliges the processor to supply crop inputs, extension service or credit in exchange for marketing agreement. Production management contract binds farmers to follow a particular production method or input regimen, usually in exchange for marketing agreement or resource provision. The most prevalent type of contract farming is market specification. In practice, out of 12 companies practicing contract farming, six companies practice the market specification contract farming, while four companies practice production management contract farming and two companies adopt resource providing contract farming. However, majority of the contract agreements are not formally documented as out of the 12 companies only 4 companies had signed a written contract agreement.

Some of the companies practicing contract farming use farmer groups as an intermediary in facilitating the 
linkages. This was particularly evident in the case of organic fruit and vegetable processors and exporters. Among the companies following this arrangement are Ceylon Organic Agriculture, which has a network of about 300 farmers belonging to five farmer groups producing mainly fruits for processing and Lanka Organic has a network of about 1,000 farmers with more than 30 farmer groups in various parts of the country producing organic fruits, spices and medicinal herbs. As shown in Fig. 2 inputs and credit are channeled through either collectors (mostly collectors are themselves farmers belonging to the group) or farmer groups. In the case of organic production, the company hires an organic certification body to carry out periodic tests in each farmer field to obtain an organic certification.

Table 04: Reliability of procurement channels by percentage responses

\begin{tabular}{lccc}
$\begin{array}{l}\text { Procurement } \\
\text { channel }\end{array}$ & Highly reliable & Reliable & Not reliable \\
\hline Spot market & 0 & $30(3)$ & $70(7)$ \\
Contract suppliers & 0 & $77(10)$ & $23(3)$ \\
Contract farmers & $18(2)$ & $82(9)$ & 0 \\
\hline
\end{tabular}

Source: Field survey (2003).

Note: Figures in parenthesis are number of responses.

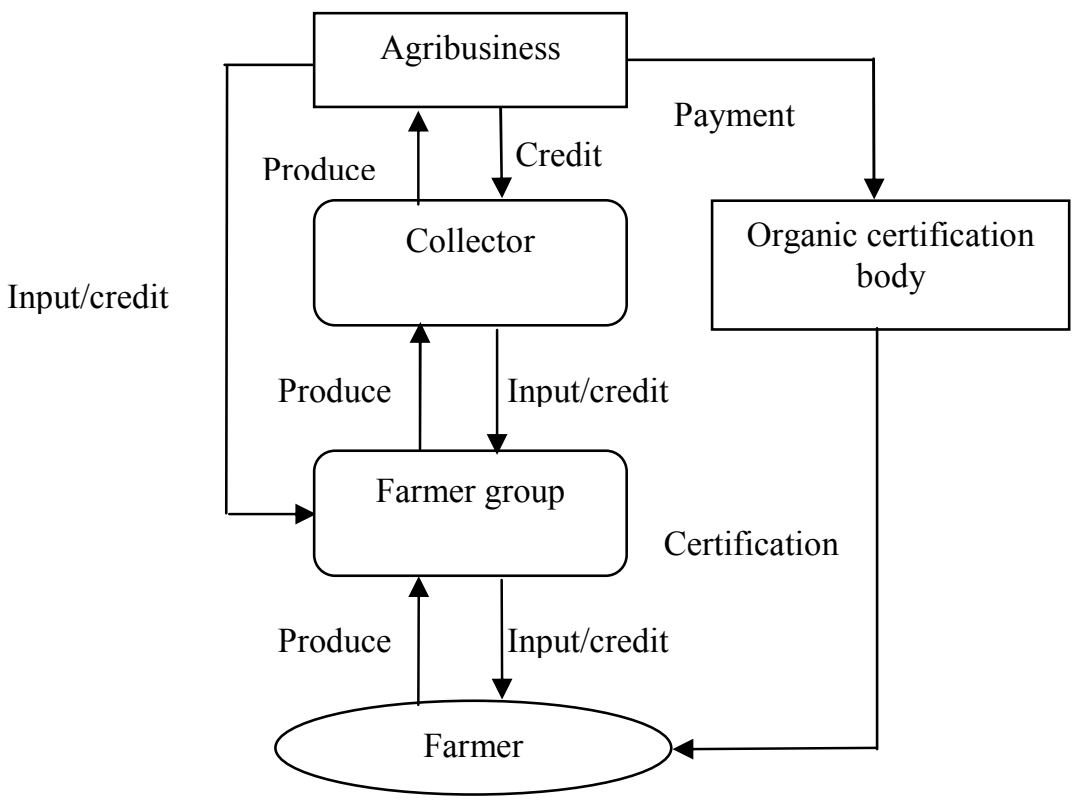

Figure 02: A model representing common production arrangements practiced by organic fruit and vegetable processors and exporters 
Companies that procured through contract farmers believe it to be the most reliable, particularly the agro processors and supermarket chain which use contract farming to ensure adequate uninterrupted supply of raw materials. This is probably due to the high asset specificity of the investments made by the agro processors and supermarket chain. However, since contract farming requires specific investments on providing credit, agricultural inputs and extension services, the exporters sparingly use contract farming. This is because the small scale of operation of exporters makes them believe that the risk of investing in contract farming is higher than the risk of raw material procurement from the spot markets.

\section{Constraints in procurement of fruits and vegetables}

The Table 5 presents the constraints faced in procuring fruits and vegetables from spot markets, contract suppliers and contract farmers. Those companies using spot market to procure fruits and vegetables report low quality and high price as two major constraints. This was clearly evident in the case of exporters of fresh fruits and vegetables as they purchased in bulk from spot market (dedicated economic centers and wholesale markets) and handpicked the best quality products for export. This resulted in 30 per cent to 40 per cent of wastage. Some companies using contract farmers to procure fruits reported lack of continuous supply as a constraint, which can be attributed to the seasonality of fruit and vegetable production. However, the supermarket chain by practicing contract farming was able to overcome seasonality and quality issues to ensure continuous supply of high quality fruits and vegetables. The seasonality problem was overcome by contract farming in different agro-ecological zones. The issue about quality was overcome by providing contract farmers with knowhow, inputs and production technology via the contract arrangement.

Regarding access to market information, about 55 per cent of companies reported that it was difficult to get market information. Apart from the market information provided by the Fruit and Vegetable Producers, Processors and Exporters Association on prices and availability of fruits and vegetables in the major wholesale markets in the Colombo city, there is no other formal organization or mechanism in place to provide market information or to carry out market matching between the industry and supplier or farmers.

\section{Industry perception of small farmers as suppliers}

Discussion with the officials of the Sri Lanka Fruit and Vegetable Producers, Processors and Exporters Association revealed that the members of the association had a positive perception towards developing supply relationships with small farmers. However, lack of proper organization models to organize small farmers resulting in high cost of establishing and managing linkages with small farmers was seen as a major constraint. 
Table 05: Constraints in fruits and vegetables procurement by percentage responses

\begin{tabular}{lcccccc}
\hline Issues & \multicolumn{3}{c}{ Vegetables } & \multicolumn{3}{c}{ Fruits } \\
\cline { 2 - 6 } & $\begin{array}{c}\text { Spot } \\
\text { market }\end{array}$ & $\begin{array}{c}\text { Contract } \\
\text { suppliers }\end{array}$ & $\begin{array}{c}\text { Contract } \\
\text { farmers }\end{array}$ & $\begin{array}{c}\text { Spot } \\
\text { market }\end{array}$ & $\begin{array}{c}\text { Contract } \\
\text { suppliers }\end{array}$ & $\begin{array}{c}\text { Contract } \\
\text { farmers }\end{array}$ \\
\hline $\begin{array}{l}\text { No } \\
\text { continuous }\end{array}$ & $38(3)$ & $30(3)$ & $43(3)$ & $22(2)$ & $29(2)$ & $67(4)$ \\
$\begin{array}{l}\text { supply } \\
\text { Low quality }\end{array}$ & $63(5)$ & $40(4)$ & $14(1)$ & $67(6)$ & $29(2)$ & - \\
$\begin{array}{l}\text { High price } \\
\text { Partial }\end{array}$ & $50(4)$ & $30(3)$ & $14(1)$ & $44(4)$ & $14(1)$ & $17(1)$ \\
$\begin{array}{l}\text { delivery } \\
\text { High } \\
\text { transport }\end{array}$ & - & $10(1)$ & - & - & - & - \\
cost & - & - & $14(1)$ & - & - & $34(2)$ \\
\hline
\end{tabular}

Source: Field survey (2003).

Notes: 1) Figures in parenthesis are number of responses.

2) The percentage responses are calculated as percentage of total companies procuring from each source. The total will not add up to $100 \%$ as some companies report more than one constraint.

Table 06: Industry perceptions of small farmers (mean scores)

\begin{tabular}{lcc}
\hline Industry perception & Mean & $\begin{array}{c}\text { Standard } \\
\text { deviation }\end{array}$ \\
\hline $\begin{array}{l}\text { Contract farming as a reliable source of } \\
\text { supply }\end{array}$ & 3.98 & 1.01 \\
$\begin{array}{l}\text { Farmers ability to supply quality raw } \\
\text { materials }\end{array}$ & 3.32 & 0.98 \\
$\begin{array}{l}\text { High transaction cost of managing } \\
\text { contracts }\end{array}$ & 3.53 & 1.24 \\
$\begin{array}{l}\text { Farmer organizations and farmer } \\
\text { companies as intermediaries in } \\
\text { facilitating contract farming }\end{array}$ & 3.92 & 0.87 \\
\hline
\end{tabular}

Source: Field survey (2003).

Note: The five point Likert scale is from strongly disagree to strongly agree.

As shown in Table 06, the survey results revealed that contract farmers were perceived to be a reliable source of fruits and vegetables supply to the industry, as the mean of score was nearly 4 . The industry has a positive perception on their capability to produce high quality products to meet the industry requirements. However, it was perceived that one major constraint faced by the industry in contracting arrangements with small farmers was the high transaction cost involved in managing the contract. This was particularly evident for exporters of fresh fruits and vegetables as these companies were relatively small scale and they could not invest in 
contract farming with small farmers. The contract farming involving high value crops entailed considerable investment to start-up and manage the contract. Furthermore, the institutional innovation in the form of farmer organizations or farmer companies was seen as an effective way to reduce the high transaction cost of setting up and managing contract farming.

\section{CONCLUSION}

Although fruits and vegetables are considered as potential crops for crop diversification in the paddy dominated non-plantation agriculture, at present only less than 4 per cent of fruit and vegetable production is utilized for value addition.

The majority of the processors and exporters of fruit and vegetable in Sri Lanka are small and medium scale industries. However, despite its relatively small size, the fruit and vegetable industry in Sri Lanka, appears to be using contract farming as an important mean to procure its raw material requirements. In general, the industry considers contract farming as a reliable source of raw material supply.

Companies in the industry have a positive perception of small farmers' ability to be contract-farming partners to supply industry requirements. However, lack of proper organization models to organize small farmers was seen as a major constraint resulting in high cost of establishing and managing linkages with small farmers. Therefore, to develop and strengthen linkages between the fruit and vegetable industry and small farmers it is necessary to organize small farmers into collective groups in the form of farmer organizations and farmer companies.

\section{References}

Central Bank of Sri Lanka (2003) Annual Report.

Dunham, D. (1995) Contract Farming and Export Horticulture: Can Agribusiness Revitalise the Peasant Sector in Sri Lanka? IPS Agricultural Policy Series, No. 3, Institute of Policy Studies, Colombo, p. 34.

Esham, M., K. Usami, H. Kobayashi and I. Matsumura (2006) An Economic Study of Contract Farming in the Fruit and Vegetable Industry in Sri Lanka: A Case Study of Gherkin (Cucumis sativus) Production, Journal of Rural Problems. Vol. 42, No. 1, pp. 14-23.

FAOSTAT (2004) FAO Statistical Database Food and Agriculture Organization, Rome.

Kudagamage, C. (1998) Present Status of Horticulture Research in Sri Lanka, Paper presented at World Conference on Horticultural Research 17-20 June1998, Rome, Italy. 